\title{
PENERAPAN MODEL PEMBELAJARAN PROBLEM SOLVING UNTUK MENINGKATKAN HASIL BELAJAR SISWA PADA TEMA KEADAAN ALAM DAN AKTIVITAS PENDUDUK INDONESIA KELAS VII D SMP ISLAM MA'ARIF 02 MALANG
}

\author{
${ }^{1)}$ Siti Nawira; ${ }^{2}$ Ika Meviana \\ 1) 2) Universitas Kanjuruhan Malang \\ Email: ${ }^{1)}$ sitinawira046@gmail.com; ${ }^{2)}$ meviana@unikama.ac.id
}

\begin{abstract}
Abstrak
Hasil pengamatan yang dilakukan di kelas VII D SMP Islam Ma'arif 02 Malang dijumpai beberapa permasalahan yaitu siswa kurang merespon apa yang dijelaskan oleh guru, kurang antusiasnya siswa saat pembelajaran, dan kurangnya komunikasi yang baik antar siswa sehingga menyebabkan hasil belajar siswa rendah. Bukti rendahnya hasil belajar dilihat dari persentase ketuntasan 33\% dengan kategori kurang baik pada mata pelajaran IPS.Problem solving merupakan model pembelajaran yang melakukan pemusatan pada pengajaran dan keterampilan pemecahan masalah yang diikuti dengan penguatan keterampilan. Penelitian ini bertujuan untuk meningkatkan hasil belajar siswa IPS pada tema keadaan alam dan aktivitas penduduk Indonesia kelas VII D SMP Islam Ma'arif 02 Malang melalui model pembelajaran problem solving. Rancangan penelitian ini menggunakan penelitian tindakan kelas model Kemmis dan Mc Taggard. Penelitian ini dilaksanakan di SMP Islam Ma'arif 02 Malang siswa kelas VII D tahun pelajaran 2017/2018 yang terdiri dari 27 siswa yaitu 15 siswa laki-laki dan 12 siswa perempuan. Instrumen yang digunakan dalam penelitian ini adalah tes, lembar observasi keterlaksanaan, dan catatan temuan lapangan.Berdasarkan hasil penelitian yang sudah dilaksanakan menunjukkan bahwa siklus I persentase hasil belajar siswa 59\% dengan nilai rata-rata 71 dengan kategori kurang baik. Sedangkan pada siklus II persentase hasil belajar siswa $81 \%$ dengan nilai rata-rata 77,07 dengan kategori sangat baik. Maka dapat disimpulkan bahwa penerapan model pembelajaran problem solving dapat meningkatkan hasil belajar siswa. Meningkatnya hasil belajar siswa diduga karena; 1) diskusi kelompok, 2) tanggung jawab pembelajaran, 3) motivasi belajar, dan 4) tanya jawab.Berdasarkan hasil penelitian, disarankan kepada guru IPS SMP Islam Ma'arif 02 Malang agar dapat menerapkan model pembelajaran problem solving dalam upaya meningkatkan hasil belajar siswa. Hasil penelitian ini dapat digunakan sebagai; 1) referensi untuk dapat menerapkan model pembelajaran problem solving dengan tujuan untuk meningkatkan hasil belajar siswa, 2) pembelajaran diharapkan dapat dilakukan dengan baik agar mendapatkan hasil yang optimal.
\end{abstract}

Kata Kunci: Problem Solving, hasil belajar

\section{PENDAHULUAN}

Hasil pengamatan yang telah dilakukan di SMP Islam Ma'arif 02 Malang berdasarkan permasalahan yang dijumpai di kelas VII D yakni siswa kurang merespon apa yang dijelaskan oleh guru, masih ada siswa yang beralasan izin keluar kelas saat pembelajaran, kurang antusiasnya siswa saat mengikuti pembelajaran, dan kurangnya komunikasi yang baik antar siswa pada saat diskusi kelompok. Penyampaian materi yang diajarkan guru kurang mendapatkan respon yang positif dari siswa karena kurangnya perhatian siswa saat pembelajaran menyebabkan hasil belajar siswa rendah.Berdasarkan hasil pengamatan, maka peneliti segera mencari solusi untuk dapat menyelesaikan permasalahan tersebut. 
Peneliti menyimpulkan bahwa permasalahan utama di kelas VII D yaitu kurangnya hasil belajar siswa.Berdasarkan kriteria ketuntasan minimal yang sudah ditetapkan dengan KKM 69.Hal ini menandakan peran guru sangat penting dalam menyampaikan materi kepada siswa.Siswa memiliki pandangan bahwa pelajaran IPS merupakan pelajaran yang hanya menghafal dan tidak terlalu penting untuk dipelajari. Maka dari itu, peneliti akan menerapkan suatu model pembelajaran agar lebih mudah guru dalam menyampaikan materi.

Penelitian ini bertujuan untuk meningkatkan hasil belajar siswa kelas VII D pada tema keadaan alam dan aktivitas penduduk Indonesia mata pelajaran IPS SMP Islam Ma'arif 02 Malang.Penerapan model pembelajaran problem solving pada tema keadaan alam dan aktivitas penduduk Indonesia untuk meningkatkan hasil belajar siswa di SMP Islam Ma'arif 02 Malang.Materi yang dipelajari pada penelitian ini adalah keadaan alam dan aktivitas penduduk Indonesia pada siswa kelas VII D di SMP Islam Ma'arif 02 Malang pada tahun pelajaran 2017/2018.

\section{METODE PENELITIAN}

Penelitian ini dirancang dengan menggunakan penelitian tindakan kelas (classroom action research). Model pembelajaran problem solving ini menggunakan rancangan penelitian tindakan kelas model Kemmis dan Taggard. Desain yang dipergunakan dalam penelitian tindakan kelas ini berbentuk siklus dari Kemmis dan Mc Taggard.Siklus ini tidak hanya berlangsung satu kali, tetapi beberapa kali hingga tercapai tujuan yang diharapkan.Rencana penelitian tindakan kelas ini terdiri dari dua siklus. Setiap siklus terdiri dari beberapa tahapantahapan sebagai berikut: 1) perencanaan, 2) pelaksanaan tindakan 3) pengamatan, dan 4) refleksi.

Penelitian ini dilaksanakan di kelas VII D SMP Islam Ma'arif 02 Malang Semester I Tahun Pelajaran 2017/2018.Penelitian ini dilakukan peneliti untuk bertindak sebagai peneliti yang bertugas sebagai perencana tindakan, pengumpul data dan pelapor hasil penelitian.Selain itu, peneliti juga berperan sebagai penyusun bahan ajar (lembar kegiatan), pelaksanaan tindakan (pengajar/guru), dan pembuat laporan hasil penelitian yang dilakukan. Sedangkan pengamat (observer) dari teman sejawat yang bertindak sebagai pengamat di kelas selama kegiatan pembelajaran berlangsung dan dibantu oleh guru IPS. Subjek penelitian merupakan siswa kelas VII D SMP Islam Ma'arif 02 Malang yang berjumlah 27 siswa, 15 siswa laki-laki dan 12 siswa perempuan. Waktu pelaksanaan penelitian pada Semester Ganjil bulan November. Instrumen yang digunakan dengan menggunakan: 1) Tes, 2) Lembar observasi keterlaksanaan, dan 3) Catatan temuan lapangan.

Hasil belajar adalah kemampuan siswa untuk memahami materi keadaan alam dan aktivitas penduduk Indonesia yang diukur dengan tes formatif untuk mendapatkan hasil perubahan tingkat pemahaman siswa yang hasil akhirnya berupa skor.Model pembelajaran probem solving merupakan pembelajaran dengan langkah melakukan pemusatan pada pengajaran dan keterampilan pemecahan masalah yang diikuti dengan penguatan keterampilan yang meliputi mencari informasi, menganalisis situasi, dan mengidentifikasi masalah dengan tujuan untuk mencari alternatif sehingga dapat 
mengambil tindakan keputusan untuk mencapai sasaran.

\section{HASIL DAN PEMBAHASAN}

Data hasil penelitian ini berupa skor hasil belajar siswa setelah diterapkan model pembelajaran problem solving dari siklus I ke siklus II.Akhir pelaksanaan siklus I diadakan tes yang terdiri dari 7 soal uraian untuk menentukan hasil belajar siswa. Berdasarkan hasil penelitian siswa yang memiliki kategori sangat baik sebanyak 8 siswa, kategori baik sebanyak 8 siswa, kategori cukup baik sebanyak 10 siswa, dan kategori kurang baik sebanyak 1 siswa. Berdasarkan hasil belajar siswa diperoleh siswa yang tuntas sekitar 16 siswa dan yang tidak tuntas sekitar 11 siswa.

Hasil belajar siswa pada siklus I dikelas VII D yang berjumlah 27 siswa dapat dilihat siswa yang tuntas 16 siswa dan yang tidak tuntas 11siswa. Hasil belajar siswa dapat diperoleh dari jumlah skor yang diperoleh siswa dikali $100 \%$ dan dibagi dengan skor maksimumnya maka mendapatkan persentase ketuntasan sekitar 59\% dengan kategori kurang baik dengan nilai tertinggi 95 dan nilai terendah 17. Dilihat dari siklus I banyak siswa yang tidak mengerjakan serta menjawab tidak sesuai dengan jawabannya.Berdasarkan uraian dapat disimpulkan bahwa pada siklus I nilai hasil belajar siswa masih rendah sehingga perlu adanya perbaikan pada siklus II.Kategori pada siklus I kurang baikmaka siswa harus memenuhi kategori yang sudah ditentukan untuk mendapatkan hasil belajar yang baik.

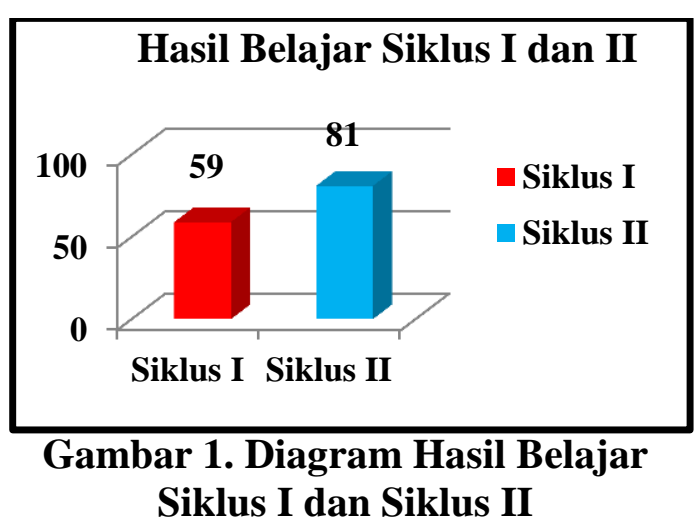

Berdasarkan analisis yang dilakukan pada siklus I maka untuk melihat lebih jelasnya ada pada tahap pelaksanaan tindakan pada siklus II. Hasil belajar yang telah diperoleh kemudian dianalisis bahwa siswa dikelas VII D yang tuntas 22 siswa dan yang tidak tuntas 5 siswa dari 27 siswa. Bahwa dari 27 siswa pada siklus II yang memiliki kategori sangat baik 14 siswa, kategori baik 8 siswa, cukup baik 5 siswa, dan kurang baik 0 siswa. Maka disimpulkan bahwa hasil belajar siswa pada kelas VII D mengalami peningkatan hasil belajar pada siklus II, dari 22 siswa yang tuntas sedangkan yang tidak tuntas 5 siswa.Hasil belajar pada siklus II sudah mengalami peningkatan. Pada diagram tersebut menunjukkan siswa yang tuntas 22 siswa dan yang tidak tuntas 5 siswa dari 27 siswa. Persentase ketuntasannya $81 \%$ dengan nilai rata-rata 77,07 dengan kategori sangat baik. Maka dari paparan data diatas dapat disimpulkan bahwa hasil belajar siswa dikelas VII D mengalami peningkatan pada siklus II dibandingkan dengan pada siklus I.

Hasil belajar siswa meningkat hal ini dilihat dari nilai hasil belajar siswa pada siklus I dan siklus II. Siklus I mendapatkan nilai rata-rata 71 dengan adanya perbaikan pada siklus II nilai rata-rata siswa meningkat menjadi 77,07 sedangkan kategorinya sangat baik. Peningkatan siklus I ke siklus II 
yaitu 5,48 yang diperoleh dari jumlah rata-rata siklus I dan II dibagi dengan jumlah siswa. Berdasarkan penerapan model pembelajaran problem solving yang dilakukan di kelas VII D memberikan hal yang positif dengan meningkatnya hasil belajar siswa. Meningkatnya hasil belajar siswa karena; 1) diskusi kelompok, 2) tanggung jawab pembelajaran, 3) motivasi belajar, dan 4) tanya jawab. Penerapan model pembelajaran yang terdapat dalam indikator keterlaksanaan model problem solving maka akan mempengaruhi hasil belajar siswa.

Pertama, diskusi kelompok.Diskusi kelompok yang dilakukan pada saat pembelajaran dapat memberikan rangsangan kepada siswa untuk meningkatkan kemampuan dalam berpikir. Pengetahuan yang diperoleh saat diskusi kelompok menjadi bekal bagi siswa untuk meningkatkan kemampuannya dalam menyelesaikan permasalahan agar mencapai pemahaman yang sama. Berdasarkan pendapat menurut Marselina (2016:69) bahwasannya diskusi kelompok dapat meningkatkan hasil belajar siswa yang dibuktikan dengan meningkatnya hasil belajar pada siklus II mencapai 86,6. Penelitian yang dilakukan dengan menerapkan model problem solving di Kelas VIII SMP 23 Malang.

Kedua, tanggung jawab pembelajaran.Tanggung jawab dalam pembelajaran memberikan hal yang positif untuk menyadarkan pemahaman siswa untuk lebih termotivasi dalam belajar.Siswa mencari dan mencoba dari berbagai kejadian untuk dapat memahaminya, bahkan seandainya informasi yang tersedia tidak lengkap.Pendapat menurut Marselina (2016:69) bahwa kemampuan siswa dalam memecahkan masalah sangat penting. Siswa tidak hanya dituntut untuk memecahkan masalah yang berkaitan dengan materi ajar tetapi juga siswa mampu mengaitkan apa yang dia terima saat pembelajaran dengan masalah nyata yang dihadapi dalam kehidupan sehari-hari.

Ketiga, motivasi belajar.Motivasi belajar secara kuat tergantung kepada kepercayaan siswa terhadap potensi belajarnya sendiri.Perasaan kompeten dan kepercayaan terhadap potensi untuk memecahkan masalah baru, diturunkan dari pengalaman langsung di dalam menguasai masalah. Adanya motivasi belajar siswa akan lebih terdorong untuk mempelajari hal yang baru dengan saling bersaing dalam hal kemampuan sehingga akan terpacu untuk lebih meningkatkan hasil belajarnya.Pendapat menurut Marselina (2016:69) bahwa faktor-faktor yang dapat meningkatkan hasil belajar siswa dengan adanya pemberian bimbingan dan arahan kepada siswa saat pembelajaran berlangsung maupun diskusi, sangat membantu mengatasi kesulitan yang dihadapi, pemberian motivasi kepada siswa juga akan membentu siswa akan pentingnya terlibat aktif pada saat kegiatan pembelajaran, dan juga kemampuan siswa dalam pemecahan masalah.

Keempat, Tanya Jawab. Karakteristiktanya jawab yaitu dengan menumbuhkan rasa ingin tahu siswa dimana siswa akan berusaha mencari jawaban atas pertanyaan yang diajukan kepadanya dengan menyimak soal atau melihat soal yang diajukan. Tanya jawab dapat membantu tumbuhnya perhatian siswa pada pelajaran, serta mengembangkan kemampuannya untuk menggunakan pengetahuannya dan pengalamannya sehingga pengetahuannya menjadi fungsional. Pendapatan menurut Prayoga (2015:49) 
dengan menerapkan model problem solving di Kelas VIII SMP NU AL Hikmah Jeru Tumpang yang mengatakan bahwa siswa mulai aktif untuk bertanya dan pada saat presentasi temannya di depan kelas. Sehingga nilai rata-rata yang diperoleh siswa mengalami peningkatan dari $78 \%$ menjadi $80 \%$ berdasarkan nilai hasil belajar siswa dari KKM yang telah ditentukan.

\section{KESIMPULAN}

Berdasarkan hasil penelitian danpembahasan maka dapat disimpulkan bahwa penerapan model pembelajaran problem solving dapat meningkatkan hasil belajar siswa Kelas VII D IPS di SMP Islam Ma'arif 02 Malang. Pada siklus I diperoleh persentase kriteria ketuntasan 59\% dengan nilai rata-rata 71 kategori kurang baik dan pada siklus II diperoleh kriteria ketuntasan $81 \%$ dengan nilai rata-rata 77,07 kategori sangat baik. Peningkatan rata-rata hasil belajar dari siklus I ke siklus II yaitu 5,48 .

\section{DAFTAR RUJUKAN}

Prayoga, Puji Sagita. 2015. Penerapan Model Pembelajaran Problem Solving Untuk Meningkatkan Hasil Belajar IPS Siswa Kelas VIII SMP NU Al-Hikmah Jeru Tumpang Tahun Pelajaran 2014/2015. Skripsi tidak diterbitkan. Malang: Universitas Kanjuruhan Malang.

Marselina, Listra Onde. 2016. Penerapan Model Pembelajaran Problem Solving Untuk Meningkatkan Keaktifan dan Hasil Belajar IPS Siswa Kelas VIII 3 SMP Negeri 23 Malang Tahun Pelajaran 2015/2016.Skripsi tidak diterbitkan. Malang: Universitas Kanjuruhan Malang. 